\title{
COVID-19 VE ÇOCUKLAR; ŞIMDIYE KADAR NELER ÖĞRENDIK?
}

\author{
Seher Palanbek Yavaş'1i, Gül Arga ${ }^{\text {iD }}$
}

\author{
1- Istanbul Üniversitesi Tıp Fakültesi Halk Sağlığı Anabilim Dalı, İstanbul, Türkiye \\ 2- Ankara Üniversitesi Tıp Fakültesi Çocuk Sağ. ve Hast. Anabilim Dalı, Ankara, Türkiye
}

\section{Özet}

Koronavirüs hastalığı 2019 (COVID-19), Aralık 2019'da Çin'in Wuhan şehrinde ortaya çıkan ve daha sonra küresel olarak yayılan bir pandemidir. Hastalığa neden olan koronovirüs; pozitif polariteli, segmentsiz, zarflı RNA virüsüdür. COVID-19 enfeksiyonun sonuçları insanlık için olumsuz olsa da, dünyada pediyatrik COVID-19 hastaları, tüm hastaların küçük bir yüzdesini oluşturur. Çocuk hastalarda ailesel kümelenme yaygın olarak görülmektedir. Genellikle ateş ile öksürüğün birlikte görüldüğü semptomlarla karakterize, yetişkinlere göre hafif seyirli ve daha iyi prognoza sahiptir. Yoğun bakım ve ölüm nadir görülmektedir. Çocuklarda hastalık tedavi yönetimi genel olarak yatak istirahati, destekleyici tedaviler, yeterli kalori ve su alımının sağlanması, elektrolit dengesi ve homestazın korunması, büyük çocuklar için gereken zamanlarda psikolojik destek verilmesi şeklinde sıralanabilir. Henüz çocuklar için etkili bir antiviral tedavisi bulunmamaktadır. Çocuk hastalar özel bir grup olduğu için dikkatle incelenmelidir. Çocuk hastaların epidemiyolojik analizinin yapılması daha etkili önleyici tedbirler ve tedavi çözümlerinin bulunmasına olanak sağlayabilir. Bu derleme, çocuklarda COVID-19 hakkında mevcut bilinenleri özetlemektedir.

Anahtar Kelimeler: COVID-19, SARS-CoV-2, çocuklar, yenidoğan.

\section{COVID-19 AND CHILDREN; WHAT HAVE WE LEARNED SO FAR?}

Coronavirus disease 2019 (COVID-19) is a pandemic that appeared in Wuhan, China in December 2019, and then spread globally. The disease-causing coronavirus; positively polarized, non-segmented, enveloped RNA virus. Although the consequences of COVID-19 infection are negative for humanity, pediatric COVID-19 patients make up a small percentage of all patients worldwide. Familial clustering is common in pediatric patients. It is generally characterized by fever and cough symptoms, has a mild course than adults and has a better prognosis. Intensive care and death are rare. . Disease treatment management in children can be listed as bed rest, supportive treatments, ensuring adequate calorie and water intake, maintaining electrolyte balance and homeostasis, and providing psychological support when needed for older children. There is no effective antiviral treatment for children yet. Pediatric patients should be carefully examined as they are a special group. Performing epidemiological analysis of pediatric patients may allow more effective preventive measures and treatment solutions. This review summarizes what is known about COVID-19 in children.

Key words: COVID-19, SARS-CoV-2, children, newborn.

Sorumlu Yazar / Corresponding Author: Seher Palanbek Yavaş

Istanbul Üniversitesi Tıp Fakültesi Halk Sağlığı Anabilim Dalı, Istanbul, Türkiye

e-mail: seher_palanbek@hotmail.com ORCID: 0000-0002-2452-9502

Diğer Yazarlar: Gül Arga: 0000-0002-4846-5945

Geliş tarihi / Received: 28.06.2020, Kabul Tarihi / Accepted: 14.09.2020

Nasıl Atıf Yaparım / How to Cite: Yavaş SP, Arga G. COVID-19 ve Çocuklar; Şimdiye Kadar Neler Öğrendik? ESTÜDAM Halk Sağlığı Dergisi. 2020;5(COVID-19 Özel Sayısı):96-107. 


\section{Giriş}

A ralık 2019'da Çin'in Wuhan şehrinde ortaya çıkan ve daha sonra küresel olarak yayılan bir salgın meydana geldi. Çin Hastalık Kontrol ve Önleme Merkezi, bu salgına yeni bir zarflı RNA koronavirüs üyesinin neden olduğunu açıkladı (1). Uluslararası Virüslerin Taksonomisi Komitesi bu yeni koronavirüsün adını "Şiddetli Akut Solunum Sendromu Koronavirüs 2" (SARS-CoV-2) olarak belirledi (2). Dünya Sağlık Örgütü (WHO) SARS-CoV-2'nin neden olduğu bu hastalığı, Korona Virüsü Hastalığı 2019 (COVID-19) olarak tanımlandı ve ardından 11 Mart'ta dünya çapında bir pandemi olduğunu ilan etti (3). 10 Eylül itibariyle 216 ülkede 27.688.740 onaylanmış vaka ve 899.315 ölüm gerçekleşmiştir (4). Türkiye'de ise şimdiye kadar 286.455 vaka ve 6.895 ölüm görülmüştür (10 Eylül itibariyle) (5). Şiddetli Akut Solunum Yolu Sendromu SARS-CoV-2 enfeksiyonunun teyit edilen ilk pediatrik vakası Ocak ayında Shenzhen'de bildirilmesinin ardından Çin'de pediyatrik olgu serileri yayınlanmaya başlanmıştır $(6,7)$. Çocuklarda şimdiye kadar teşhis edilen COVID-19 vakaları, tüm vakaların \% 1-5'ini oluşturmuştur. Mevcut olan kanıtlar çocukların erişkinlere oranla daha hafif semptomlara sahip olduğunu; öksürük ve ateşin ise en sık görülen semptomlar olduğunu belirtilmiştir. Yetişkinlerden farklı olarak yine gastrointestinal semptomları bildirme olasılığının yüksek olduğu da saptanmıştır. Bununla birlikte enfekte olmuş çocukların hafif klinik bulgu veya asemptomatik olması nedeniyle yetişkinlere oranla daha az vaka tespit edilmiş olabileceği açıklanmıştır. Bu nedenle popülasyon taraması yapılmadan tam olarak çocuklarda hastalığın yaygınlığının belirlenmesi zordur. Yapılan çalışmalar yine çocuklarda ve ölümlerin nadir olduğunu göstermiştir (8-10).

Var olan bilgiler COVID-19'un çocuk ve ergen ölümleri üzerindeki doğrudan etkisinin çok sınırlı olduğunu göstermiş olsa da, devletlerin sağlık sistemleri üzerindeki yükün artması, hane halkında gelir kaybı, bakım arama davranışlarının aksaması ve aşılama gibi önleyici sağlık hizmetlerinin alımının ertelenmesi gibi nedenlerle çocuk sağ kalımı üzerindeki dolaylı etkilerin öne çıkacağı vurgulanmıştır. Johns Hopkins Bloomberg Halk Sağlığı Okulu tarafından yürütülen, 118 düşük ve orta gelirli ülkeyi kapsayan araştırmaya göre, rutin sağlık hizmeti kapsama düzeylerindeki düşüşler nedeniyle sadece altı ayda var olan ölümlere ek olarak yaklaşık 1,2 milyon beş yaş altı ölüm meydana gelebileceği belirtilmiştir $(11,12)$.

\section{Viroloji}

Memelilerde ve kuşlarda hastalığa sebep olan koronovirüsler, yapısında bulunan spike glikoproteini nedeniyle elektron mikroskopunda altında taç şeklinde görünürler ve Latince'de taç anlamına gelen "Korona" adını almışlardır (13). Filogenetik analizde SARS-CoV-2 betakoronovirüs içerisinde yer alır. Koronovirüsler pozitif polariteli, segmentsiz, zarflı pleomorfik RNA virüsleridir. Genom boyutları 26 ile $32 \mathrm{~kb}$ arasında değişir ve bu özellikleri sebebiyle en büyük pozitif polariteli RNA genomuna sahip virüs ailesidir. SARS-CoV-2 ayrıca SARS-CoV ile \%79 ve MERS-CoV ile sekans benzerliği gösterir. Koronovirüs genomu Spike glikoprotein (S), Nükleokapsid (N) proteini, Membran proteini $(\mathrm{M})$ ve Zarf proteini $(E)$ olmak üzere 4 ana yapısal proteine sahiptir ve bu yapısal proteinler genomun 3'ucunda sentezlenir, şekil 1'de gösterilmiştir $(14,15)$. 


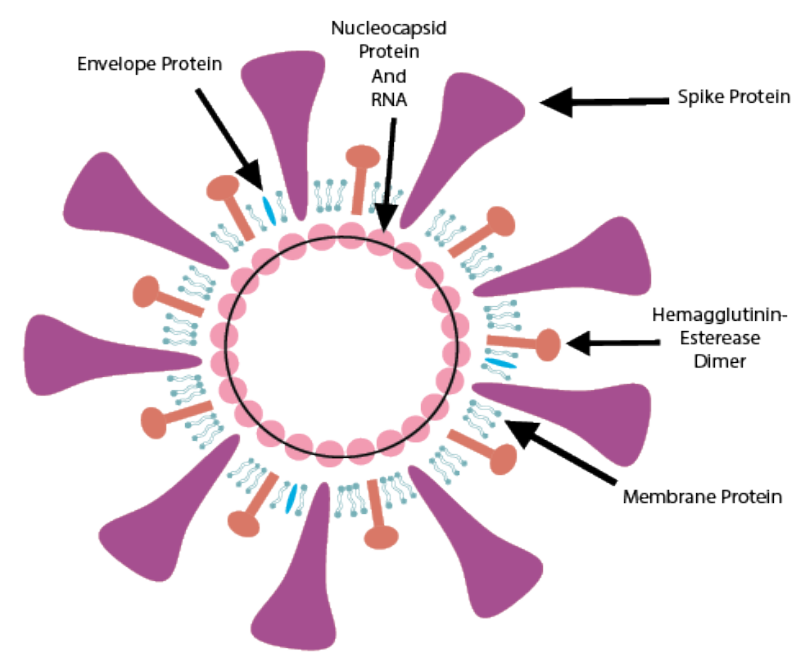

Şekil 1: SARS-CoV-2'nin genel yapısı.

Zoonotik koronovirüsler 1960 yıllardan itibaren bilinmekteydiler, Çin'in Guangdong eyaletinde 2002 ve 2003 yıllarında şiddetli akut solunum sendromu (SARS) ortaya çıkana kadar insanlar için yüksek derecede patojenik oldukları düşünülmemiştir. $\mathrm{O}$ zamana kadar koronovirüsler genel olarak nispeten hafif klinik semptomlarla, kendi kendini sınırlayan üst solunum yolu hastalığı (soğuk algınlığı) ve bağırsak enfeksiyonlarıyla ile ilişkilendirilmiştir. Sadece belirli gruplarda ise (yaşlı veya bağışıklığı baskılanmış kişilerde) ciddi hastalıklara neden olduğu ve sıklıkla hastaneye yatmayı gerektiren astım veya kronik obstrüktif akciğer hastalığı gibi önceden var olan durumların alevlenmesine yol açtığı bildirilmiştir(16).

\section{Epidemiyoloji}

Çocuklarda SARS-CoV-2 hakkındaki mevcut veriler, önceki SARS-CoV ve MERS-CoV'a benzer bir şekilde her yaştan çocuğun hastalanabileceği ancak yaygınlık ve şiddet olarak erişkinlere oranla nispeten daha az etkilendiklerini göstermiştir. İlk onaylanmış pediyatrik SARS-CoV-2 vakası 20 Ocak'ta
Shenzhen'de bildirilmiştir (6). Bununla birlikte retrospektif bir çalışmada solunum yolu enfeksiyonu nedeniyle hastaneye yatırılan 16 yaşından küçük 366 çocuğun 6'sının $(\% 1,6)$ COVID-19 teşhisi aldığı doğrulanmıştır bu da bize daha erkende başlamış olabileceğini düşündürmektedir (17).

WHO-Çin ortak komisyonu tarafından 20 Şubat'ta yayınlanan raporda 55.924 laboratuvar tarafından doğrulanmış vakalarda ortanca hasta yaşı 51 olarak belirtilmiş olup, bu vakaların \%2,4'nü çocuklar oluşturmuştur. Hastalıktan etkilenen çocukların durumu \%2,5'i ağır hasta ve $\% 0,2$ 'si kritik olarak belirtilmiştir (18). Yine Çin Kuzey'inde bulunan 6 ilde 15 Ocak 21 Şubat arasında 31 çocuğa COVID-19 tanısı koyulmuştur. Hastaların ortanca yaşı $7,1 \quad(6$ ay-17 yıl) arasındaydı. Ayrıca 21 çocuğun (\% 68) doğrulanmış yetişkin bir hastayla temas öyküsü vardı, 28 çocuğun (\% 90) enfekte aile üyesi vardı (19). Pediyatrik vakaların genellikle hasta bir ebeveyn ya da aile üyesi tarafından enfekte edildiği bilinmektedir. Başka bir çalışmada bir çalışmaya göre, enfekte çocukların \% 71,2 'sinin (183) hane halkı teması olduğu bildirilmiştir (20). Singapur'da 11 Martta 167 doğrulanmış COVID-19 çocuk hasta olduğu bildirilmiştir. $\mathrm{Bu}$ çocukların \%3,6'sı 6 ay ve 17 yaş aralığında olduğu ve 3 çocuğun aslında Wuhan'da yaşadığı saptanmıştır (21). Aynı tarihlerde Kore'de 7.755 laboratuvar tarafından doğrulanmış vaka olduğu açıklanmıştır. $\mathrm{Bu}$ hastaların 75 'i $(\% 1,0)$ 0-9 yaşları arasında ve 405 ' $i$ ise $(\% 5,2) \quad 10-19$ yaşları arasındaydı. Ayrıca bu yaş gruplarında hiç ölüm olmadığı da rapor edilmiştir. Kore'deki COVID-19 insidansı güncel nüfus verileriyle yaşlarında 100.000 'de 1.8 ve $10-19$ yaşlarında 100.000 'de 8.2 olarak hesaplanmaktadır 
$(22,23)$.

Avusturalya'da yayınlanan raporda 20 Nisan 2020 itibariyle teşhis edilen 6566 vakanın 74'ünü (\%1) 0-9 yaş arası çocukların ve 195'ni (\%3) 10-19 yaş arası çocukların oluşturduğu saptanmıştır. Yeni Zelanda'da ise aynı tarih (20 Nisan) itibariyle teşhis edilen onaylanmış ve olası vakaların 1440 olduğu bu vakaların 34'ünü (\%2) 0-9 yaş arası, 114'nü ise (\%8) 10-19 yaş arası çocukların oluşturduğu belirtilmiştir (10).

Çok merkezli olarak yapılan Avrupa (25 ülke) kohortunda Nisan ayında (1-24 Nisan) çalışmaya alınan 18 yaş ve altı 582 COVID-19 vakasının medyan yaşı 5.0 (Çeyrekler arası aralık 0.5-12) olduğu ve kadın erkek oranının ise 1'e 15 (1/15) olduğu belirlenmiştir. Aynı zamanda çocukların \%75'nin (437) bilinen bir rahatsızlığı olmadığı; kalan \%25'i arasında ise en sık rastlanan medikal durumun kronik solunum yolu hastalıkları olduğu bildirilmiştir (24).

İspanya'da yapılan bir çalışmada Madrid'te 4.695 doğrulanmış vakanın $41^{\prime}$ ini $(\% 0,8) \quad 18$ yaşının altındaki çocukların oluşturduğu saptanmıştır. Hastaların medyan yaşı 3 yıl olarak (çeyrekler arası aralık, 0.9-6 yıl) belirlenmiştir. 41 çocuğun $25^{\prime} \mathrm{i}$ (\%60) hastanede ve 4'ü (\%97) ise yoğun bakımda tedavi görmüştür. Hiçbir vakada ölüm bildirilmemiştir (25).

İtalya'da yapılan çok merkezli bir çalışmada laboratuvarda doğrulanmış 168 hastanın medyan yaşı 2,3 yıl (1 gün-17,7 yıl) olarak bulunmuştur. Hastaların \%55,9'unu erkekler oluşturmuştur. Bu hastalar arasından 2 çocuk için yoğun bakım intiyacı olduğu, 5 çocuğun nöbet geçirdiği, 49'nun deneysel tedavi gördüğü sonuç olarak hepsinin iyileştiği bildirilmiştir (26).

Yaşanılan coğrafi konuma bağlı olarak değişmekle birlikte çocuk hastalar toplam hastaların Amerika'da \%1,7'sini, İtalya'da \%1,2'sini, Çin'de \%2,1'ni, İspanya'da \%0,8'ni oluşturmaktadır. Şimdiye kadar yapılan çalışmalarda da belirtildiği gibi COVID-19 salgınından çocuklar yetişkinlere göre nispeten daha az etkilenmiştir (23-27).

\section{Bulaşıcılık}

SARS-CoV-2 virüsü ile çocukların enfekte olma ve virüsü yayma derecesi hala tam olarak cevaplanamamış bir sorudur. Bununla birlikte ülkelerin ne zaman, nasıl okulları açacakları ve sosyal mesafeyi nasıl gevşetecekleri bu enfeksiyonun çocuklar üzerindeki geniş etkilerini değerlendirebilmek adına değerlidir. Ayrıca çocukların kronik hastalığa sahip erişkinlere virüsü bulaştırması intimali göz önünde bulundurulmalıdır (28).

Salgının erken evresinde onaylanan 425 vakanın bulaşma dinamikleri incelendiğinde, 1 Ocak 2020'den önceki vakaların \%55'nin Huanan Güney Çin Deniz Ürünleri Pazarı ile bağlantıı olduğu, ancak bu tarihten sonraki vakaların sadece \%8,6'sının Pazara bağlı olduğu bulunmuştur. Bu da; sağlık çalışanlarındaki enfeksiyonlarda dahil olmak üzere, Aralık 2019 ortasından bu yana yakın temaslar sırasında kişiden kişiye yayıldığını doğrulamaktadır (29).

Bulaşma esas olarak semptomatik kişilerden başkalarına bir kişi nefes verdiğinde, hapşırdığında veya öksürdüğünde üretilen solunum damlacıkları ile yakın temasla, enfekte kişilerle doğrudan temasla veya kontamine nesneler ve yüzeylerle temas yoluyla gerçekleşir. Virüsün havadaki iletimi henüz doğrulanmamıştır. Virüsün inkübasyon süresinin 1 ila 14 gün arasında değiştiği ve medyan bulaşma süresinin 5 ila 6 gün arasında olduğu 
bilinmektedir (30). Bazı hastalar kuluçka döneminde, yani genellikle semptomlar başlamadan (presemptomatik dönemde) bulaştırıcı olabilirler. Çin'deki vakaların \%12,6'sında ve Singapur'da yapılan çalışmada ise vakaların \%6,4'ünde presemptomatik bulaş tespit edilmiştir $(31,32)$.

\section{Asemptomatik}

taşıyıcılardan yayılmanın mümkün olduğuna dair kanıtlar vardır ancak Dünya Sağlık Örgütü'ne göre asemptomatik bireylerin virüsü bulaştırma olasılığı semptomu bulunan hastalara göre daha az olduğunu bildirmiştir. Bir çalışma asemptomatik bir hastanın 455 kişiyle (diğer hastalar, aile üyeleri ve sağlık çalışanları dahil) temasından sonra temaslıların hiçbirinin enfekte olmadığını ortaya çıkarmıştır. Toplumda asemptomatik vaka prevelansını belirlemek zordur (33). Bir modelleme çalışmasında karantinaya alınan cruise gemisindeki yolcu ve mürettebatın yakın izlemi ve tekrar testleri sonucunda enfeksiyonu doğrulanmış 700 hastanın \%18'nin asemptomatik olduğu bildirilmiştir (34). İtalya'da karantinaya alınmış 3000 kişinin yaşadığı bir köyde, asemptomatik vaka oranının \%50 ile \%75 arasında olduğu belirtilmiştir. Aile kümelerinde asemptomatik bulaşma bildirilmiştir (35). Çocuklarda asemptomatik vaka oranının önemli olduğu ve enfeksiyonun toplum yayılımında rol oynayabileceği düşünülmektedir. Çalışmalar çocuklarda asemptomatik enfeksiyon sıklığının \% 4,4 ile \% 16,0 arasında değişebileceğini belirtmiştir (36,37). Bununla birlikte asemptomatik bir çocuğun okuldaki yakın etkileşimlere rağmen 172 yakın temaslıya hastalığı bulaştırmadığını belirten olgu sunumu yayınlanmıştır. Bu da; çocuklarda farklı bulaşma dinamiklerinin olabileceği gibi genellikle asemptomatik çocukların bulaşma oranlarına katkısının az olması semptomatik bir hane üyesi olmasıyla da ilişkilendirilebilir (38). Avustralya'da yapılan bir toplum tabanlı izlem çalışmasında ise öğrenciler arasından yalnızca iki ikincil vaka (indeks vakaya sekonder) olduğu saptanmıştır. Fransa'da ise okullar kapanmadan 15-17 yaş arasında öğrencileri arasında bulaşma olduğu ancak daha küçük kardeşler arasında ikincil vakanın çok az görüldüğü tespit edilmiştir (39).

Virüs kan, beyin omurilik sıvısı, perikardiyal sıvı, plasenta dokusu, idrar, tükürük, gözyaşı ve konjonktival sekresyonlarda tespit edilmiştir ancak bu vücut sıvılarında bulunması durumunun bulaşmaya katkısı henüz net olarak bilinmemektedir. Dışkıda virüs tespit edilmiştir fakat fekal- oral bulaşmanın olduğuna dair henüz bir rapor bulunmamaktadır. İshalli hastaların dışkısında viral RNA bulunması olasıdır fakat bu sıvılarda virüsün veya viral RNA yayılımı enfektivitenin doğrudan göstergesi değildir $(27,40)$.

Anneden bebeğe anne sütü veya dikey bulaşma (vertical transmission) yoluyla virüs bulaşmasının mümkün olup olmadığı bilinememektedir. Yapılan bir metaanaliz çalışmasında 87 COVID-19 pozitif gebenin bebeklerinde dikey bulaşma oranı sıfır, hareketsiz doğum 0,002 ve yenidoğan ölümü 0,002 olarak hesaplanmıştır. (sırasıyla $p=1, p=0,86$ ve $p=0,89$ ) Birinci ve beşinci dakikada Apgar skorlarının ortalaması ise sırasıyla 8,86 ve 9,0 olarak bulunmuştur. (her ikisi için de $\mathrm{p}<, 001$ ) Bu çalışmada dikey bulaşma kanıtı, fetüs veya yenidoğan için herhangi bir tehlike olmadığı gözlemlenmiştir (41). Yapılan diğer bir çalışmada Wuhan'da COVID-19 pozitif bir gebenin çocuğunda doğumda yaklaşık 2 saat sonra 14. Güne kadar SARS-CoV-2 
karşıya yüksek IgM antikorları tespit edilmiş ve bu da dikey bulaşma olasılığını düşündürmüştür (42). Bununla birlikte yapılan diğer bir çalışmada enfekte annelerden doğan 19 yenidoğanda COVID-19'u düşündüren klinik bulgular olmadığını ve amniyotik sıvı, kordon kanı, anne sütü, yenidoğanlardan alınan nazofaringeal ve rektal sürüntüler dahil olmak üzere tüm numunelerin SARS-CoV-2 için negatif tespit edildiğini belirtmiştir. Dolayısıyla dikey bulaşma varlığı hala tartışmalıdır. Genel olarak virüs ile enfekte çocukların çoğunun ikincil vakalar olması ve COVID-19 pozitif bir yetişkine maruz kaldıktan sonra, özellikle aile içinden bulaşma, çocuklarda bulaş dinamiği üzerinde en çok üzerinde durulan konudur fakat bunu da kanitlayacak uzunlamasına kohort çalışmaları bulunmamaktadır $(43,44)$.

\section{Klinik Bulgular}

Mevcut verilere göre COVID-19'lu çocukların yetişkinlere kıyasla daha hafif semptomlar gösterdiği ve daha az hastaneye yatış gerekliliği olduğu bilinmektedir. İlk pediatrik COVID-19 hastası Shenzhen'de yaşayan 10 yaşındaki çocuk hastanın asemptomatik olduğu ancak bilgisayarlı tomografi buzlu cam görüntüsü bulunduğu bildirilmiştir (1). Çin'in kuzey bölgesinde yapılan çalışmada 31 çocuk hastanın 4'ü $(\% 12,9)$ asemptomatik, 13'ü $(\% 41,9)$ normal radyografi bulgularıyla beraber hafif semptomatik, 14'ü $(\% 45,2)$ pnömoni bulguları mevcut olduğunu göstermiştir. Hastaların 10'unda $(\% 32,3)$ hafif ateş $37,3^{\circ} \mathrm{C}-38^{\circ} \mathrm{C}$, yine 10 hastada $(\% 32,3)$ $38{ }^{\circ} \mathrm{C}$ 'nin üzerinde ateş ölçülmüş olup, hastaların ateşinin 1-9 arasında sürdüğü ve 15 hastada $(\% 75,0)$ ateşin ilk 3 gün içerisinde düştüğü belirtilmiştir.
Hastaların 14'ünde $(\% 45,2) \quad$ kuru öksürük, 3 hastada baş ağrısı veya baş dönmesi, 3 hastada yorgunluk, 2 hastada rinore ve 2 hastada boğaz ağrısı saptanmıştır (19).

Yapılan bir meta analiz çalışmasında (33 çalışma ve 19 vaka raporunun dahil edildiği) çocukların $\% 17,4$ 'nün $\quad(\% \quad 95 \quad \mathrm{GA}=9,1-27,3)$ asemptomatik olduğu, ateş (\% 51,2,\% 95 $\mathrm{GA}=40,2-62,2)$ ve öksürüğün (\% 37,0,\% $95 \mathrm{Cl}=25,9-48,8)$ ise en sık semptomlar olduğunu belirlemiştir. Şiddetli veya kritik hastalık prevalansı yaklaşık olarak $\% 0$ olduğu saptanmıştır (\% $95 \mathrm{GA}=0-1,0)$. Pediyatrik hastalarda en sık görülen anormal laboratuvar bulguları lökopeni / lenfopeni (\% 28,9,\% 95 GA = 19,5-39,2) ve artmış kreatin kinaz (\% 20,1,\% 95 $\mathrm{GA}=1,3-49,9)$ olduğu bildirilmiştir. Pnömoni tanısı almış çocukların\% 53,9'unun (\% 95 GA $=38,4-68,7)$ BT taramasında ise buzlu cam opasitesi gözlenmiştir (45).

Başka bir meta analiz çalışmasında ise (48 çalışma ve 5829 pediyatrik hastanın dahil edildiği); hastaların \%20'si asemptomatik (\%95 GA:\%14-26, I2 =\% $91,4)$, \%33'ü orta (\%95 GA:\%23-43, 12 $=\% 95,6)$ ve $\% 51$ 'i hafif (\%95 GA:\%42$61,12=\% 93,4) \quad$ olarak enfeksiyonu geçirmekte olduğu saptanmıştır. 1 yaşın altındaki çocuklar arasında, kritik vakaların \%14'ü (\%95 GA:\%13-34, I2 $=\% 37.3$ ) oluşturduğu belirlenmiştir. Tipik klinik belirtilerin ateş \%51 (\%95 GA: $\% 45-57$, I2 =\%78,9) ve öksürük $\% 41$ (\%95 GA:\%35-47, I2 =\%81,0) olduğu saptanmıştır. Laboratuvar bulgularında \%16 lenfopeni (\%95 GA:\%11-21, I2 =\% 76.9) ve $\% 37$ yüksek kreatin kinaz $M B$ düzeylerinin (CK-MB) (\%95 GA:\%25 ila 48, $12=\% 59,0)$ varlığı belirlenmiştir. Ayrıca vakaların \%33'ünde (\%95 GA:\% 18-67, I2 =\%0,0) kusma gözlendiği bildirilmiştir (46). 
Çin'de yapılan bir araştırmada ise $94(\% 4,4)$ çocuğun asemptomatik, 1.088 $(\% 51,0)$ çocuğun hafif semptomatik ve $826(38,7)$ çocuğun ise orta decede semptomatik olduğunu ve 1 çocuğun öldüğünü belirlemişlerdir (17). Yapılan sistematik derlemede; çocuk hastaların şimdiye kadar teşhis edilen COVID-19 vakalarının $\% 5$ 'ten az bir kısmını oluşturduğu, genellikle yetişkinlerden daha hafif hastalığı geçirdikleri ve ölümlerinin nadir olduğunu bildirmiştir. Yine tanı bulgularının yetişkinlere benzer şekilde ateş ve solunum semptomplarının ön planda olduğu ancak yetişkinlere oranla daha az sayıda çocuğun ciddi pnömonisi olduğu saptanmıştır. İnflamatuar belirteçlerin yüksekliği daha az ve lenfositopeni ise daha nadir gözlemlenmiştir (8). Yenidoğanlarda yapılan bir çalışmada 10 yenidoğan bebeğin 6'sının Pediatrik Kritik Hastalık Skoru (PCIS) skoru 90'dan düşük olduğu bulunmuştur. Klinik olarak en çok gözlenen semptom nefes darlığı $(n=6)$ olmakla beraber, ateş $(n=2)$, anormal karaciğer fonksiyonu $(n=2)$, kalp atım hızında artış $(n=1)$, kusma $(n=1)$ ve pnömotoraks $\quad(n=1) \quad$ gözlenmiştir. Yenidoğanlardan 1 tanesinin öldüğü bildirilmiştir (44). Çin'de yapılan başka bir çalışmada 171 COVID-19'lu hastanın medyan yaşı 6,7 yıl olarak bulunmuştur. Hastalık süresince çocukların $\% 41,5$ 'inde ateş görüldüğü, öksürük ve faringeal eritemin de ateşten sonra en sık görüldüğü belirtilmiştir. Toplam 27 hastanın $(\% 15,8)$ herhangi bir enfeksiyon veya radyolojik görüntülemelerinde pnömoni bulgusu olmadığını ve 12 hasta da pnömoni radyolojik bulunmasına rağmen enfeksiyon semptompları olmadığı saptanmıştır. En sık radyolojik bulgu ise bilateral buzlu cam opasitesi $(\% 32,7)$ olarak bildirilmiştir. Yoğun bakım desteği ve invaziv mekanik ventilasyon 3 hasta için gerekli olmuştur. Bu hastalarda aynı zamanda hidronefroz, lösemi ve intusussepsiyonda bulunmuştur (36). Türkiye'de 30 Mart'ta açıklanan rapora göre ise 11.535 hastadan 117'si (\%1) pediyatrik hasta grubunu oluşturuyordu. Hastaların \%13,6'sı 1 yaşın altındaydı ve 3 yenidoğan bulunmaktaydı. Hastaların yaklaşık \%53'ü erkekti ve \%48,7'sinde temas öyküsü bulunmaktaydı (47). COVID-19 ile enfekte yetişkinlerin aksine çocukların çoğunda daha hafif bir klinik seyir görüldüğü saptanmıştır. Çocukların daha aktif doğal bağışıklık yanıtı oluşturmaları, daha sağlıklı solunum yollarına sahip olmaları (yetişkinlerden daha az sigara dumanına ve hava kirliliğine maruz kalmaları nedeniyle) ve daha az kronik hastalığa sahip olmaları şeklinde yorumlanabilir. Ayrıca çocuklar yetişkinler tarafından korunurlar ve eğer ailede pozitif bir vaka bulunmuyorsa, hastalanma olasılıkları azalır. Yetişkinler ve çocuklar arasında hastalık seyri açısından gözlemlenen fark Renin-anjiyotensin sistemindeki (RAS) reseptörlerdeki farklılıklar ve patojenlere karşı değişen inflamatuar yanıtlarla ilişkili olabilir $(48,49)$.

\section{Tanı ve Tedavi}

Hastalardan solunum sistemi örnekleri alıp, SARS-CoV-2 RNA'sının gerçek zamanlı revers transkriptazpolimeraz zincir reaksiyonu (RT-PZR) ile gösterilmesi enfeksiyonun tanısının doğrulanmasında altın standarttır. Virüsün üst solunum yolunda replikasyonu yüksek olmasından dolayı Dünya Sağlık Örgütü ayaktan tedavi gören hastalardan nazofaringeal ve orofaringeal sürüntü veya yıkama örneklerinin beraber alınmasını önermektedir. Ciddi akciğer rahatsızlığı bulunan hastalardan balgam (hasta 
çıkarabiliyorsa), endotrakeal aspirat (ETA) veya bronkoalveoler lavaj sIvisı (BAL) gibi alt solunum yolu örnekleri alınabilir. Bu işlemler yapılırken yüksek riskli aerosolizasyona dikkat edilmeli, uygun koruyucu ekipman kullanılmalı ve enfeksiyon kontrol önlemleri tam olarak alınmalıdır. Enfeksiyonu bulguları olup olası vaka tanımına uyan fakat alınan bir veya daha fazla RT-PZR sonucu negatif gelen hastalarda, COVID-19 şüphesi dışlanmamalıdır. Bu hastalarda klinik, radyolojik ve laboratuvar bulguları doğrultusunda vaka yönetimi yapılmalıdır (49).

Hastalıktan etkilenen çocuklar için SpO2 ve diğer vital bulguların düzenli takip edilmesi; durumu ciddi ve kritik hastaların mümkün olduğunca erken belirlenmesi önemlidir. Çocuklarda Hastalık tedavi yönetimi genel olarak yatak istirahati, destekleyici tedaviler, yeterli kalori ve su alımının sağlanması, elektrolit dengesi ve homestazın korunması, büyük çocuklar için gereken zamanlarda psikolojik destek verilmesi şeklinde sıralanabilir. Henüz çocuklar için etkili bir antiviral tedavisi bulunmamaktadır. İnterferon- $\alpha 2 b$ ile nebulizasyon uygulanabilir. Akılcı olmayan kullanımından kaçınılmalıdır. İyi yapılan bakteriyolojik izlemden sonra, ikincil bakteriyel enfeksiyon kanıtı varsa uygun antibiyotikler zamanında

Tablo 1: Çocukluk çağında tedavide kullanılabilecek ilaçların dozları ve uygulama şekilleri.

\begin{tabular}{|c|c|c|}
\hline İlaç Adı & $\begin{array}{l}\text { Günlük çocuk dozu ve uygulama } \\
\text { yolu }\end{array}$ & $\begin{array}{l}\text { Tedavi } \\
\text { Süresi } \\
\text { (gün) }\end{array}$ \\
\hline \multicolumn{3}{|l|}{ İlk Tercih } \\
\hline $\begin{array}{l}\text { Hidroksiklorokin, } \\
200 \mathrm{mg} \text { tablet }\end{array}$ & $\begin{array}{lllr}\text { İlk gün } 6.5 \text { mg/kg/doz günde } 2 \text { kez } \\
\text { Hidroksiklorokin } & \text { sülfat; ilk } & \text { gün } \\
\text { maksimum } & \text { doz: } & 400 & \mathrm{mg} / \mathrm{doz} ; \\
\text { devamında } & 2-5 & \text { günlerde } & 3.25 \\
\mathrm{mg} / \mathrm{kg} / \mathrm{doz} & \text { günde } & 2 & \mathrm{kez} \\
\text { Hidroksiklorokin } & \text { sülfat: } & \text { maksimum } \\
\text { doz } 200 \mathrm{mg} / \mathrm{doz} & & \end{array}$ & 5 gün \\
\hline \multicolumn{3}{|c|}{ İlerleme Durumunda veya Alternatif Tedavi } \\
\hline $\begin{array}{lcc}\text { Lopinavir } 250 & \mathrm{mg} / \\
\text { ritonavir } 50 & \mathrm{mg} \\
\text { tablet } & & \end{array}$ & \begin{tabular}{|l}
14 gün - 6 ay arası çocuklarda: \\
Lopinavir komponenti 16 mg/kg PO \\
BID \\
6 ay - 18 yaş arası: \\
15-25 kg: 200 mg-50 mg PO BID \\
26-35 kg: 300 mg-75 mg PO BID \\
>35 kg: 400 mg-100 mg PO BID
\end{tabular} & 10-14 gün \\
\hline \multicolumn{3}{|c|}{ Veya 15 yaşından büyük çocuklarda } \\
\hline $\begin{array}{l}\text { Favipiravir } 200 \mathrm{mg} \\
\text { tablet }\end{array}$ & $\begin{array}{l}2 \times 1600 \mathrm{mg} \text { yükleme, } \\
2 \times 600 \mathrm{mg} \text { idame }\end{array}$ & 5 gün \\
\hline
\end{tabular}


kullanılmalıdır. Kortikostereoid kullanımından kaçınılmalıdır. Hastalığın gidişatında ARDS, ensefalit veya ensefalopati, septik şok gibi ciddi komplikasyonlar görülürse düşünülebilir. Esas olarak klinik tedavi hastaların semptomlarını hafifletmeye, hastalıktan kaynaklanan komplikasyonların destekleyici yönetimi ve oluşan metabolik dengesizliği düzeltmeye yöneliktir $(7,9,27)$.

Sağlık Bakanlığı'nın yayınladığı raporda; çocuklarda COVID-19 enfeksiyonuna yönelik tedaviler ile ilgili, bugün için bilimsel kanıt düzeyi yeterli olan veri bulunmadığı; bu nedenle çocuklarla ilgili COVID-19 tedavi önerileri erişkin çalışmalarına göre değerlendirilmeli ve çocuk hastanın durumuna göre planlanmaması gerektiği açıklanmıştır. Yine çocuklarda ilaçların olası yan etkileri de tedavi kararı verirken göz önüne alınmalıdır. Buna göre kullanılabilecek ilaçların dozları ve süreleri Tablo 1'de belirtilmiştir (50).

\section{Sonuç}

Çocuklar dahil olmak üzere herkesin
COVID-19 pozitif bir hastayla teması sonucunda hastalanma olasılığı vardır bu nedenden dolayı çocuklar covid-19'dan korunmuş bir grup olarak düşünülmemelidir. Her ne kadar yayınlanan raporlarda çocukların yetişkinlere oranla daha hafif hastalığı geçirdikleri düşünülse de hastalığı şiddetli geçiren vakalar ve ölüm görülmüştür. Asemptomatik çocuklar birçok ülkede SARS-CoV-2 için test edilmemiştir ve dolayısıyla hastalığın çocuklardaki prevelansı tam olarak bilinmemektedir. Çocukların hastalığı yayılımında önemli bir rolü olduğu bilinmektedir bu nedenle koruyucu önlemlerin alınması erişkinlere bulaşı önlemede etkili bir yöntem olarak düşünülmelidir. Hastalığı önleme, korunma ve kontrol çalışmaları bulaşıcı hastalıklarda, özellikle COVID-19 gibi çok bulaşıcı bir virüs için tedaviden daha önce gelmektedir. Yaşadığımız viral pandemiyle savaşmak için, farklı yaş gruplarından çocukların korunması, hastalığa duyarııı̆ı ve hastalığın mekanizması hakkında ileri araştırmalar yapılabilir. 


\section{Kaynaklar}

1. Li Q, Guan X, Wu P, Wang X, Zhou L, Tong Y, et al. Early transmission dynamics in Wuhan, China, of novel coronavirusinfected pneumonia. New England Journal of Medicine. 2020;382(13): 1199-207.

2. Coronaviridae Study Group of the International Committee on Taxonomy of Viruses. The species Severe acute respiratory syndrome-related coronavirus: classifying 2019-nCoV and naming it SARS-CoV-2. Nat Microbiol. 2020;5(4): 536-44. doi:10.1038/s41564-020-0695-z

3. World Health Organization. Coronavirus disease 2019 (COVID-19). Situation report-51 [Internet]. URL:http://www.who.int/ docs/default-source/coronaviruse/situation-r eports/20200311sitrep-51-covid-19. pdf. Available:27.06.2020

4. Coronavirus disease (COVID-19) outbreak situation. URL: https://www.who.int/ emergencies/diseases/novel-coronavirus-20 19 Erişim Tarihi:10.09.2020

5. T.C. Sağlık Bakanlığı COVID-19 Bilgilendirme Sayfası.Erişim Adresi: https://covid19.saglik.gov.tr/TR-66935/genelkoronavirus-tablosu.html Erişim Tarihi: 11.09.2020

6. Chan JF, Yuan S, Kok KH, To KK, Chu Het al. A familial cluster of pneumonia associated with the 2019 novel coronavirus indicating person-to-person transmission: a study of a family cluster. Lancet 2020; 395: 514-23.

7. Chen Z, Fu J, Shu Q Chen Y, Hua $C$ et al. Diagnosis and treatment recommendations for pediatric respiratory infection caused by the 2019 novel coronavirus. World Journal of Pediatrics. World J Pediatr 2020;16 (3):240-6.

8. Ludvigsson JF. Systematic review of COVID-19 in children show milder cases and a better prognosis than adults. Acta Paediatri. 2020;109(6):1088-1095. doi: 10.1111/apa.15270

9. Balasubramanıan S, Rao, Goenka A, Roderick M, Ramanan A. Coronavirus Disease 2019 (COVID-19) in Children - What We Know So Far and What We Do Not.
Indian Pediatrics. 2020 May 15;57(5):435-42. doi: 10.1007/s13312-020-1819-510

10. COVID-19 in children. Erişim Adresi: https://www.health.govt.nz/system/files/docu ments/publications/covid-19-in-children-2ma y2020.pdf Erişim Tarihi:11.09.2020

11. Malık YA. Properties of Coronavirus and SARS-CoV-2. Malaysian J Pathol 2020; 42(1) : $3-11$.

12. Roberton $T, E D$, Chou VB, Stegmuller $A R$, Jackson BD, Tam Y, Sawadogo-Lewis T, Walker N..Early estimates of the indirect effects of the COVID-19 pandemic on maternal and child mortality in low-income and middle-income countries: a modelling study. Lancet Glob Health. 2020; 8: e901-08.

13. Evren E, Us E. COVID-19 Etkeni. Memikoğlu O, Genç V.editör. COVID-19. 1.Basım. Ankara Üniversitesi Basımevi; 2020:1-8.

14. Malık YA. Properties of Coronavirus and SARS-CoV-2. Malaysian J Pathol 2020; 42(1) : 3-11.

15. SARS-COV-2 (COVID-19, 2019-nCoV) Reagents. URL: https://www.prosci-inc.com/ covid-19/. Available:27.06.2020

16. Enjuanes L, Zuñiga S, Castaño-Rodriguez C,Gutierrez-Alvarez ,.Canton J,Sola I. Molecular Basis of Coronavirus Virulence and Vaccine Development. Advances in Virus Research.2016; (96): 245-86.

17. Liu W, Zhang $Q$, Chen J, Xiang R, Song $H$, Shu S, et al. Detection of COVID-19 in children in early January 2020 in Wuhan, China. New England Journal. 2020;382(14): 1370-1.doi: 10.1056/NEJMc2003717.

18. World Health Organization. Report of the WHO-China joint mission on COVID-19, 16-24 February 2020. Geneva (Switzerland): World Health Organization; 2020.

19. Wang $D$, Ju XL, Xie F, Lu Y, Li FY, Huang HH, et al. Clinical analysis of 31 cases of 2019 novel coronavirus infection in children from six provinces (autonomous region) of northern China. Zhonghua Er Ke Za Zhi. 2020 ;(4): 269-74.

20. Choi S, Kim HW, Kang J, Kim DH, Cho EY. Epidemiology and clinical features of 
coronavirus disease 2019 in children. Korean Journal of Pediatrics. 2020;63(4):125-32. doi: 10.3345/cep.2020.00535

21. Singapore Government Agency. COVID-19: cases in Singapore: 2020 Erişim Adresi:https://www.gov.sg/article/covid-19-ca ses-in-singapore.Erişim Tarihi:12.03.2020

22. Korea Centers for Disease Control and Prevention. The updates of COVID-19 in Republic of Korea, as of 11 March, 2020. Cheongju (Korea): Korea Centers for Disease Control and Prevention, 2020.

23. Korean Statistical Information Service (KOSIS). Registered population by administrative: Statistics Korea; Erişim Adresi: http://kosis.kr/ statHtml/statHtml.do? orgld=101\&tblld=DT_1B04006\&conn_path $=$ I 2. Erişim Tarihi: 20.03 .2020

24. Götzinger F, Santiago-García B, Noguera-Julián A,Lanaspa M, Lancella L, Calò Carducci Fl et al. COVID-19 in children and adolescents in Europe: a multinational, multicentre cohort study. Lancet Child Adolesc Health 2020; 4: 653-61.

25. Tagarro A, Epalza $C$, Santos $M$, et al . Screening and severity of coronavirus disease 2019 (COVID-19) in children in Madrid, Spain. JAMA Pediatri. $2020: 8$; e 201346 .d o i : 10.1001/jamapediatrics.2020.1346.

26. Garazzino S, Montagnani C, Donà $D$, et al. Multicentre Italian study of SARS-CoV-2 infection in children and adolescents, preliminary data as at 10 April 2020. Euro Surveill. 2020; 25(18) 05.

27. BMJ, Coronavirus Disease 2019 (COVID-19). Erişim Adresi: https://bestpractice.bmj.com/topics/en-gb/30 00168/epidemiology\#referencePop4 Erişim Tarihi:15.06.2020.

28. Viner RM, Mytton OT, Bonell C, Melendez-Torres G.J, Ward J, Hudson L et al.Susceptibility to SARS-CoV-2 infection amongst children and adolescents compared with adults: a systematic review and meta-analysis. preprint doi: https://doi.org/1 0.1101/2020.05.20.20108126. ErişimAdresi:h ttps://www.medrxiv.org/content/10.1101/202 0.05.20.20108126v1.full.pdf
29. Paraskevis D, Kostaki EG, Magiorkinis G, et al. Full-genome evolutionary analysis of the novel corona virus (2019-nCoV) rejects the hypothesis of emergence as a result of a recent recombination event. Infect Genet Evol. 2020;79:104212. doi: 10.1016/ j.meegid.2020.104212.

30. World Health Organization. Clinical management of COVID-19: interim guidance.2020[internetpublication].URL:http s://www.who.int/publications/i/item/clinical-m anagement-of-covid-19 Available:27.06.2020.

31. Wang Z, Ma W, Zheng X, et al. Household transmission of SARS-CoV-2. Journal of Infectious. 2020;(1):179-82.

32. Li W, Zhang B, Lu J, et al. The characteristics of household transmission of COVID-19. Clin Infect Dis. 2020 April 17.doi: 10.1093/cid/ciaa450.

33. Li C, Ji F, Wang L, et al. Asymptomatic and human-to-human transmission of SARS-CoV-2 in a 2 family cluster, Xuzhou, China. Emerg Infect Dis. 2020;(7):1626-8.

34. Mizumoto K, Kagaya K, Zarebski A, et al. Estimating the asymptomatic proportion of coronavirus disease 2019 (COVID-19) cases on board the Diamond Princess cruise ship, Yokohama, Japan, 2020. Euro Surveill. 2020;25(10). https://doi.org/10.2807/15607917.ES.2020.25.10.2000180

35. Day M. Covid-19: identifying and isolating asymptomatic people helped eliminate virus in Italian village. BMJ. 2020 Mar 23;368:1

36.Lu X, Zhang L, Du H, et al. SARS-CoV-2 Infection in Children. $N$ Engl $J$ Med. 2020;382(17):1663-5.

37. Dong Y, Mo X, Hu Y, Qi X, Jiang F, Jiang Z, Tong S. Epidemiology of COVID-19 Among Children in China. Pediatrics. 2020;145(6):e20200702. doi: 10.1542/peds. 2020-0702.

38. Jiang $X L$, Zhang $X L$, Zhao $X N$, et al. Transmission potential of asymptomatic and paucisymptomatic SARS-CoV-2 infections: a three-family cluster study in China J Infect Dis. 2020;221(12):1948-52.

39. (NCIRS) NCfIRaS. COVID-19 in schools - the experience in NSW. Sydney: NSW Government, 2020. 
40. Xiao $F$, Sun $J, X u Y$, et al. Infectious SARS-CoV-2 in feces of patient with severe COVID-19. Emerg Infect Dis. 2020 May 18;26(8). doi: 10.3201/eid2608.200681.

41. Kasraeian $M$, Zare $M$, Vafaei $H$, et al. COVID-19 pneumonia and pregnancy; a systematic review and meta-analysis. $J$ Matern Fetal Neonatal Med. 2020:19;1-8.doi: 10.1080/14767058.2020.1763952.

42. Dong L, Tian J, He S, Zhu C, Wang J, Liu C, et al. Possible vertical transmission of SARS-CoV-2 from an infected mother to her newborn. JAMA. 2020;323(18):1846-8.

43. Chen H, Guo J, Wang C, Luo F, Yu X, Zhang $W$, et al. Clinical characteristics and intrauterine vertical transmission potential of COVID-19 infection in nine pregnant women: a retrospective review of medical records. Lancet. 2020;395(10226):809-15.

44. Zhu H, Wang L, Fang C, Peng S, Zhang L, Chang $G$, et al. Clinical analysis of 10 neonates born to mothers with 2019-nCoV pneumonia. Transl Pediatr. 2020;9(1):51-60.
45. Ding $Y$, Yan $H$, Guo $W$. Clinical Characteristics of Children With COVID-19: A Meta-Analysis. Front Pediatr. 2020; 8: 431. doi: 10.3389/fped.2020.00431.

46. Cui X, Zhao Z, Zhang T, Guo W, Guo W, Zheng $J$ et al. A systematic review and meta-analysis of children with Coronavirus Disease 2019 (COVID-19). J Med Virol. 2020;10.doi: 10.1002/jmv.26398.

47. Tezer H, Demirdağ TB.Novel coronavirus disease (COVID-19) in children. Turk J Med Sci (2020) 50: 592-603.

48. Lee PI, Hu YL, Chen PY, Huang YC, Hsueh $P R$. Are children less susceptible to COVID-19? Journal of Microbiology Immunology and Infection. 2020;53(3):371-2.

49. Öcal D, Vezir S, Karahan ZC. Mikrobiyolojik Tanı Yöntemleri. Memikoğlu O, Genç V.editör. COVID-19. 1.Basım. Ankara Üniversitesi Basımevi; 2020:1-8.

50. T.C. Sağlık Bakanlığı, Covıd-19 Çocuk Hasta Yönetimi Ve Tedavi. Erişim Adresi:https://covid19.saglik.gov.tr/Eklenti/38 596/0/covid-19rehbericocukhastayonetimivet edavipdf.pdf. Erişim Tarihi:11.09.2020 